\title{
KONTEKS LAHIR DAN BERKEMBANGNYA KEKRISTENAN MULA-MULA
}

Tujuan uraian topik ini untuk menyajikan apa yang telah menyebabkan

Kekristenan dapat lahir dan berkembang selama tiga abad pertama. Kekristenan telah dimulai dari sebuah "benih" yang telah ditaburkan di bumi ini, dan melalui "benih" itu banyak orang dari berbagai suku bangsa telah mendapatkan keselamatan. Sejarah Kekristenan akan menunjukkan bahwa "benih" itu telah bertumbuh dalam kehidupan umat manusia, bahkan telah berangsur-angsur tersebar ke seluruh dunia. Itulah yang telah dilakukan oleh Yesus Kristus, Sang Penebus, Juruselamat umat manusia, seperti yang tersirat di dalam pernyataan berikut ini:

Kekristenan sebagai sesuatu yang telah turun dari atas, ketika surga terbuka bagi suatu kehidupan manusia yang terjatuh, yaitu suatu kuasa yang asal mula dan hakekatnya dimuliakan atas segala sesuatu, sehingga sifat dasar manusia dapat tercipta dari kuasa itu, ditujukan untuk memberikan suatu kehidupan baru bagi manusia. Sumber utama dari kuasa itu adalah Dia yang hidupnya ditunjukkan manifestasinya pada kita, yaitu Yesus dari Nazareth, Penebus umat manusia yang dijauhkan Allah karena dosa. ${ }^{1}$

Pada waktu Kekristenan telah dimulai pada tiga abad pertama, berbagai

kondisi di wilayah Mediteranian telah mempersiapkan jalan untuk lahirnya sebuah iman agama baru dan perkembangannya di daerah itu. Sesungguhnya sesudah itu, ketika Kekristenan berdiri sebagai suatu agama yang paling kuat di wilayah itu, kondisi seperti itu tidak pernah lagi terjadi pada masa-masa berikutnya, di mana Kekristenan bisa masuk dan diterima sebagai suatu iman yang baru. ${ }^{2}$

Berkenaan dengan itu ternyata wilayah Mediteranian telah menjadi tempat lahir dan berkembangnya Kekristenan mula-mula. Sesudah itu tidak ada lagi kesempatan

\footnotetext{
${ }^{1}$ Augustus, Neander, General History of the Christian Religion and Church, pen., Joseph Torrey (London: Henry B. Gohn, 1853), I:2. (Terjemahan Langsung).

${ }^{2}$ Kenneth Scott Latourette, A History of the Expansion of Christianity, The First Five Centuries (Grand Rapids Michigan: Zondervan Publishing House, 1970), I:8. (Terjemahan Langsung).
} 
dan peluang seperti yang telah terjadi pada abad pertama sampai ketiga di wilayah tersebut, yang menyebabkan Kekristenan bisa berkembang dengan begitu cepatnya.

Hal yang sangat menarik telah dikemukakan oleh seorang ahli sejarah dunia bahwa wilayah Mediteranian memiliki agama-agama yang unik dan telah menjadi latar belakang bagi tiga kepercayaan besar di dunia yang terkait dengan bahasa Semit (Semitic). Ketiganya telah mempengaruhi dan mengubah kondisi budaya manusia. Ketiga kepercayaan itu adalah Keyahudian dengan monoteisme-nya, Kekristenan sebagai agama universal, dan kebangkitan Islam. ${ }^{3}$ Di seputar wilayah Mediteranian dan Timur Tengah, tiga kepercayaan tersebut telah tersebar untuk pertama kalinya, kemudian mencapai berbagai wilayah yang lain.

Dalam bagian-bagian di bawah ini akan diuraikan tentang apa yang berkembang di wilayah Mediteranian, termasuk di dalamnya agama-agama, budayabudaya, dan lain-lain yang pada waktu itu telah mempengaruhi lahirnya Kekristenan dan perkembangan-perkembangannya.

Gambaran tentang luasnya wilayah ini telah dilaporkan sebagai berikut:

Wilayah Mediteranian ini terbentang dari Persia di bagian timur sampai ke Spanyol di bagian barat, dalam kurun waktu antara abad keempat (Sebelum Masehi) sampai dengan abad pertama pada masa Kekristenan. Melihat luasnya wilayah Mediteranian, dan keberadaannya dalam kurun waktu yang cukup lama, maka tidak mengherankan jika dunia pada masa kuno tersebut telah menyebabkan munculnya berbagai macam kebudayaan seperti: peradaban Mesir, kebudayaan Mesopotamia, muncul dan berkembangnya Zoroastrianisme, kebudayaan dan agama-agama Yunani dan Romawi, dan juga berkembangnya agama-agama misteri yang pada waktunya menyaingi Kekristenan. ${ }^{4}$

Meskipun beberapa dari unsur-unsur peradaban ini tidak ada lagi pada masa sekarang ini, misalnya agama kuno Babilonia dan agama kuno Mesir yang telah

\footnotetext{
${ }^{3}$ Ninian Smart, The Religious Experience of Mankind (New York: Charles Scribner's Sons, 1984) III:239. (Terjemahan Langsung) .

${ }^{4}$ Ibid.
} 
ditelan oleh budaya modern, namun unsur-unsur tersebut di atas sangat penting dalam sejarah manusia, khususnya dalam mempelajari sejarah lahir dan berkembangnya Kekristenan. Agama-agama dan budaya-budaya tersebut telah menunjukkan adanya usahausaha yang dilakukan manusia untuk mengisi kerinduannya akan keselamatan umat manusia. Memang agama-agama itu sesungguhnya tidak memberi jaminan yang pasti tentang keselamatan seseorang, namun itu semua telah membukakan kebutuhan manusia yang paling dalam, yaitu apa yang harus diperbuat oleh seseorang agar dia memperoleh kehidupan yang tidak fana.

Bagian berikut ini akan diuraikan adanya tiga sejarah bangsa yang telah mempengaruhi lahir dan berkembangnya Keristenan pada tiga abad pertama. Masing-masing telah memberikan sumbangsih dengan cara yang khas, sehingga itu telah turut serta mempersiapkan lahan untuk penanaman Kekristenan. Ketiga bangsa itu ialah Yahudi dari aspek keagamaan, Romawi dari aspek politik, dan Yunani dari aspek ilmu dan seni.

\section{Kekaisaran Romawi}

Para penulis Perjanjian Baru telah menyatakan secara jelas tentang apa yang terjadi ketika kelahiran Yesus ke dunia, bahwa Dia dilahirkan pada masa pemerintahan Kaisar Augustus ketika Kuirinius menjadi Gubernur Siria. ${ }^{5}$ Peristiwa kelahiran Yesus juga dituliskan oleh Lukas "pada waktu Herodes menjadi raja di Yudea."6 Catatan-catatan itu menunjukkan siapa pemerintah yang sedang berperan pada waktu kelahiran Yesus Kristus abad pertama. Ternyata telah ada suatu sistem pemerintahan yang kuat dan rapi pada masa kelahiran Yesus ke bumi. Meskipun pada waktu tertentu pemerintahan Romawi yang berkuasa telah menjadi musuh utama Kekristenan, namun demikian melalui pemerintahan itu

\footnotetext{
${ }^{5}$ Luk. 2:2.

${ }^{6}$ Luk. 1:5.
} 
juga telah diperoleh nilai-nilai individu yang berkaitan dengan kebebasan untuk beragama.

Secara politik, pemerintahan Kaisar Augustus yang dibangun oleh Julius

Caesar dan atas fondasi yang diletakkan melalui masa penaklukan Romawi yang begitu panjang, telah menciptakan Kekaisaran Romawi. ${ }^{7}$ Pemerintahan Kaisar Augustus telah menghasilkan perdamaian bagi dunia pada masa itu, sebelum masa tersebut telah terjadi peperangan sipil antara kelompok-kelompok pemimpin yang ambisius, sehinga telah menimbulkan kekacauan. Batas-batas Kekaisaran Romawi telah mencakup suatu bagian terbesar dari wilayah Mediteranian, kesatuan dalam satu pemerintahan ini tidak pernah terjadi sebelumnya. ${ }^{8}$ Bahkan selama dua abad di bawah kekaisaran yang didirikan, wilayah yang luas ini telah menikmati kedamaian dan yang tidak pernah terjadi sebelumnya bahkan tidak pernah terulang lagi. ${ }^{9}$ Kaisar Augustus telah membuat perubahan-perubahan penting di dalam pemerintahan Roma, Itali dan provinsi-provinsi. Sebagian besar perubahan-perubahan itu telah berpengaruh dalam mengurangi hasil yang tidak tepat guna dan korupsi, penghapusan hambatan untuk kedamaian dan keteraturan oleh ambisi pribadi-pribadi, dan pengurangan pembedaan antara orang-orang Roma dengan orang-orang Itali, para senator dengan para penunggang kuda. ${ }^{10}$

Nampak bahwa kesatuan secara politik di dalam wilayah Kekaisaran Romawi telah menyebabkan ada perdamaian di dalam kehidupan masyarakatnya. Kedamaian di dalam suatu masyarakat akan menghasilkan kestabilan dan pertumbuhan di bidang perekonomian serta berkurangnya diskriminasi tingkat sosial.

Jadi secara politis, dunia yang di dalamnya Gereja lahir dan berkembang

\footnotetext{
${ }^{7}$ Latourette, A History of the Expansion of Christianity, The First Five Centuries, 8. ${ }^{8}$ Ibid.

${ }^{9}$ Ibid.

${ }^{10}$ Albert M. Craig, The Heritage of World Civilizations (New York: Macmillan Publishing Company, t.t), 186. (Terjemahan Langsung).
} 
dibagi atas dua Negara besar, yaitu Kekaisaran Romawi dan Kerajaan Partia (Persia).

Kekaisaran Romawi meliputi daerah-daerah di sekitar Laut Tengah, sedangkan Kerajaan Partia (Persia) meliputi wilayah Irak dan Iran sekarang. ${ }^{11}$

Selain perdamaian yang dihasilkan oleh kesatuan politik di wilayah

Kekaisaran Romawi, nampak juga adanya perkembangan jalan-jalan raya dan perdagangan. Perkembangan ini memungkinkan lajunya perjalanan kelompokkelompok, pribadi-pribadi, dan pertukaran ide-ide. Bukan secara kebetulan Kekristenan telah meluas dalam jalur-jalur perjalanan dan berakar di kota-kota di mana perdagangan telah tersebar. ${ }^{12}$

Jadi penyebaran Kekristenan berjalan seiring dengan penyebaran perdagangan. Jalan-jalan raya yang dibangun telah menyebabkan lancarnya komunikasi antar kota, sehingga perdagangan dan lalu lintas di darat dan di laut mempererat hubungan antar semua wilayah Kekaisaran. Itulah sebabnya keadaan ini telah berguna bagi usaha-usaha pekabaran Injil oleh para Rasul dan Penginjil-penginjil yang harus bepergian ke mana-mana untuk memasyurkan Nama Tuhan. ${ }^{13}$ Perjalanan-perjalanan Paulus dan perkembangan Gereja yang pesat itu akan sukar diartikan, jika tidak mengingat keadaan dunia zaman itu seperti keadaan di atas. ${ }^{14}$ Untungnya bagi para misionari awal, keadaan lingkungan sangat menunjang bahkan hampir ideal untuk menyebarkan iman Kristen. Ada peluang yang sangat besar bagi mobilitas di dalam wilayah Kekaisaran Romawi pada masa Kristus. Yang mengherankan lagi jalan-jalan yang tersusun secara baik merupakan suatu undangan terbuka bagi orang-

\footnotetext{
${ }^{11}$ Van Den End, Harta dalam Bejana, Sejarah Gereja Ringkas (Jakarta: BPK Gunung Mulia, 1990), 9.

${ }^{12}$ Latourette, A History of the Expansion of Christianity, The First Five Centuries, 9.

${ }^{13}$ Berkhof dan Enklaar, Sejarah Gereja (Jakarta: BPK Gunung Mulia, 1992), 1

${ }^{14}$ Ibid.
} 
orang untuk bergerak, dan kedamaian yang relatif telah menyebabkan perjalananperjalanan lebih menarik untuk dilakukan. ${ }^{15}$

Faktor bahasa sebagai komunikasi antar pribadi atau kelompok juga menjadi unsur yang penting dalam perkembangan di Kekaisaran Romawi. Bahasa Yunani dipakai sebagai bahasa semua kelompok masyarakat, bahkan menjadi bahasa penulisan literatur-literatur atau membaca secara intensif di beberapa pusat-pusat utama tempat tinggal penduduk. ${ }^{16}$ Dengan adanya bahasa persatuan yang dipakai oleh masyarakat luas di Kekaisaran Romawi telah menjadi salah satu faktor yang penting dalam perluasan Kekristenan abad pertama sampai ketiga.

Meskipun kondisi yang sama di atas, yaitu kedamaian, kesatuan politik, perdagangan, kesatuan bahasa, tingkat toleransi yang adil, atau pertumbuhan keseragaman budaya, dapat muncul di suatu wilayah yang lain, namun itu belum tentu cukup untuk menyebabkan perkembangan Kekristenan secara cepat. Ada factor-faktor lain yaitu situasi agama dan sosial, keduanya sangat menentukan lahir dan berkembangnya Kekristenan di Kekaisaran Romawi.

\section{Keistimewaan dari orang Romawi yaitu mengaitkan secara erat antara agama} dengan politik. Yang satu memberi hidup untuk yang lain. Dalam hal ini, seluruh isi sosial dan politik telah didasarkan pada kebiasaan keagamaan, yang dalam hubungannya dengan kesederhanaan sikap menyajikan suatu perlawanan yang menyolok dengan mitologi Yunani, yaitu suatu sistem di mana unsur-unsurnya bersifat estetika dari pada moral, bahkan yang tidak surut dari sebuah kesatuan

\footnotetext{
${ }^{15}$ Ruth A. Tucker, From Jerusalem to Irian Jaya, A Biographical History of Christian Missions (Grand Rapids Michigan: Academie Books Zondervan Publishing House, 1983), 25.

${ }^{16}$ Latourette, A History of the Expansion of Christianity, The First Five Centuries, 9.
} 
yang terbuka dengan kelakuan tidak bermoral. ${ }^{17}$ Orang-orang Romawi dapat memakai keputusan-keputusan politik dan militer setelah berkonsultasi secara rinci dengan keinginan dari ilah-ilah mereka. ${ }^{18}$

Dapat dikatakan bahwa kestabilan politik di wilayah Kekaisaran Romawi telah menjadi faktor penunjang pada lahirnya Kekristenan pada abad pertama. Faktor ini juga telah memicu berkembangnya sistim perdagangan karena adanya pembangunan jalan-jalan raya yang mengakibatkan kelancaran hubungan antara kota yang satu dengan kota lainnya, ini memungkinkan untuk terjadinya pergerakan orang-orang dari satu wilayah ke wilayah yang lain. Faktor bahasa persatuan yang dipakai orang-orang di lingkungan kekaisaran itu, yaitu bahasa Yunani, ini juga telah menimbulkan komunikasi yang lancar antar pribadi dan kelompok masyarakat.

Unsur lain yang juga sangat menentukan lahir dan berkembangnya Kekristenan di wilayah Kekaisaran Romawi yaitu faktor keagamaan. Telah terjadi kehausan rohani yang besar pada masa itu karena adanya perkembangan kepercayaan terhadap penyembahan pada kaisar. Orang-orang Romawi sangat meyakini bahwa di dalam diri seorang Kaisar terdapat titisan keilahian, ada hubungan yang erat antara pemerintah dengan keilahian. Mereka percaya bahwa seorang Kaisar adalah inkarnasi dari keilahian. ${ }^{19}$ Pada era ini Kekristenan nampaknya bukan hanya diperhadapkan dengan bangkitnya penyembahan resmi kepada Kaisar, namun juga suatu penyebaran secara luas tentang filsafat Yunani. Ini adalah era yang penuh dengan kreativitas dan keaslian untuk berpikir. Pada bagian berikut ini akan diuraikan tentang pengaruh filsafat Yunani di dalam Kekaisaran Romawi.

\footnotetext{
${ }^{17}$ Neander, General History of the Christian Religion and Church, 7

${ }^{18}$ Ibid., 275.

${ }^{19}$ Latourette, A History of the Expansion of Christianity, The First Five Centuries, 10.
} 


\section{Filsafat Yunani}

Sebagian besar para Bapak Gereja adalah orang Yunani dan orang Romawi yang berasal dari bangsa kafir. Pada waktu dihadapkan pada kesulitan membawa iman Kristen kepada orang-orang sezamannya, mereka terpaksa menghubungkannya dengan pola pikir pada zaman itu yaitu filsafat Yunani. ${ }^{20}$ Ada tiga aliran filsafat penting yang mempengaruhi penulis-penulis Kristen pertama: Platonisme yang diprakarsai oleh Plato (meninggal tahun 347 SM), murid Socrates (meninggal tahun 399 SM); Aristotelianisme yang diprakarsai oleh Aristoteles (meninggal tahun 322 SM), murid Plato; dan ajaran Stoa yang diprakarsai oleh Zeno (meninggal tahun 263 SM). Ketiganya adalah kelompok pemikir yang berbeda satu dengan yang lain, namun pada awal Kekristenan banyak saling mempengaruhi. ${ }^{21}$

Pendapat lain mengemukakan bahwa dalam mendalami pengaruh dari filsafat sekuler bagi pembentukan doktrin Kristen, pembatasan perlu diberikan pada dua sistem filsafat yaitu Platonisme dan Aristotelanisme. ${ }^{22}$ Ada beberapa keuntungan dalam pembatasan dari dua pikiran filsafat ini, karena alas an-alasan berikut ini:

Pertama, kedua pikiran filsafat itu menggunakan pengaruh pada metode intelektual manusia, dari pada kombinasi sistem yang lain. Pikiran-pikiran itu tentunya telah dipengaruhi oleh pikiran Yunani, budaya Yunani, lebih dari sistem filsafat yang lainnya. Keduanya itu muncul kembali dalam filsafat Romawi, sejauh Romawi mempunyai suatu filsafat. Kita melihat bahwa Plato, Aristoteles, Cicero telah lebih banyak mempengaruhi para Bapak Gereja, para orang terpelajar, para

\footnotetext{
${ }^{20}$ Tony Lane, Runtut Pijar Sejarah Pemikiran Kristiani (Jakarta: BPK Gunung Mulia, 1990), 4.

${ }^{21}$ Ibid.

${ }^{22}$ William G. T. Shedd, A History of Christian Doctrine (London: Hamilton, Adams \& Co, 1863), I:51. (Terjemahan Langsung).
} 
tokoh Reformasi seperti Calvin dan Melanchton. ${ }^{23}$

Kedua, pikiran-pikiran filsafat ini berisi lebih banyak kebenaran dari pada sistem lain yang tidak berasal dari mereka. Pikiran-pikiran ini berisi sebuah gambaran tentang kekuatan-kekuatan dan fungsi-fungsi, hukum-hukum, eksploitasi-eksploitasi, dan hubungan-hubungan dari pikiran manusia, yang dekat dengan soal realitas dari fakta, yang tidak ditemukan dalam sistem yang berbeda lainnya. ${ }^{24}$

Ketiga, di dalam kedua pikiran filsafat ini diketemukan hakekat persesuaian satu sama lainnya. Platonisme dan Aristotelianisme hanya berbeda dalam bentuk, namun tidak berbeda dalam substansinya. Ada persesuaian substansi antara Plato dan muridnya Aristoteles, mengenai rasionalitas dan imoralitas tentang pikiran yang berbeda dengan benda; mengenai sifat dan asal dari ide-ide; mengenai posisi relatif dan pentingnya pengertian, dan pengetahuan melalui pengertian. ${ }^{25}$

Dengan mengetahui catatan-catatan di atas maka dapat terlihat hubungan Platonisme dengan Aristotelianisme, sehingga pada bagian-bagian berikut ini akan dapat dipelajari bagaimana kedua aliran filsafat tersebut telah mempengaruhi pikiranpikiran para tokoh gereja pada masa awal Kekristenan, khususnya pada abad pertama sampai ketiga.

Pada masa kelahiran Kristus, sekitar abad pertama, dan masa terdahulu, sebenarnya aliran filsafat dunia sedang berada dalam status penurunan yang dalam, dan berkembang korupsi. ${ }^{26}$ Aliran Filsafat yang menekankan tentang usaha-usaha pencarian

\footnotetext{
${ }^{23}$ Ibid., 52.

${ }^{24}$ Ibid., 53.

${ }^{25}$ Ibid., 57.

${ }^{26}$ Ibid., 60.
} 
manusia, begitu juga dengan intelektual manusia pada umumnya, sedang berada dalam titik terendah pada masa tersebut. Meskipun demikian, berikut ini akan diuraikan beberapa kelompok aliran filsafat yang tetap ada pada masa-masa tersebut. Kelompok-kelompok utama filsafat Yunani yang ada di dalam Kekaisaran Romawi, yaitu: golongan Epicureanisme, golongan Peripatetik (para pengikut Aristoteles), golongan Pythagoras, golongan Stoik, golongan Platonisme, dan golongan Neoplatonisme.

Golongan Epicureanisme, yaitu suatu golongan yang pada pokoknya ada di antara orang-orang terpelajar dan kalangan tingkat atas. Pemimpin kelompok ini menekankan pada kasih sayang, yang mengajarkan bahwa manusia dapat bergembira di tengah penderitaan, dan dirinya sendiri menemui kekalahan dan kesulitan dengan keberanian yang tinggi. Golongan ini tidak pernah mendorong seseorang pada kesenangan, melainkan hidup sederhana dan mencari pembebasan umat manusia. ${ }^{27}$ Ini adalah salah satu buah dari pengaruh pikiran Lucretius pada abad pertama (Sebelum Masehi), yang secara tegas menyerang ketahyulan dan agama tradisional. ${ }^{28}$ Menurut dia, akhir dari hal utama yang dicari manusia adalah kesenangan, namun ini bukan berarti bahwa seseorang harus hidup dalam suatu perilaku yang penuh kesenangan secara nyata. Agar supaya memperoleh kesenangan yang maximum, seseorang perlu menjadi bijaksana dan mengendalikan nafsu, dan sopan dalam kehidupan sosial dan budaya seseorang. Para ilah tidak ditolak, namun mereka tidak punya hubungan dengan urusan manusia. ${ }^{29}$ Sebenarnya pikiran aliran ini ingin mengarah pada perlawanannya terhadap agama yang sudah ada dan ketahyulan orang-orang pada masa itu. Sehingga banyak orang terpelajar menjadi sangat tahu dengan hasil pikiran

\footnotetext{
${ }^{27}$ Latourette, A History of the Expansion of Christianity, The First Five Centuries, 16.

${ }^{28}$ Smart, The Religious Experience of Mankind, 276.

${ }^{29}$ Ibid.
} 
mereka. Golongan Epicurean adalah kelompok aliran filsafat yang paling berpengaruh pada masa kelahiran Kristus, karena kelompok ini cocok untuk mengubah sifat manusia, dan memiliki sedikit atau sama sekali tidak mempunyai karakter keilmuan sehingga mudah dimengerti dan diterima oleh kelompok orang banyak. $^{30}$

Golongan Peripatetik, meskipun pengikut golongan ini telah melanjutkan tradisi Aristoteles yang menjadi sangat penting di Eropa pada masa abad pertengahan, namun pada masa permulaan Kekristenan golongan ini tidak begitu terkenal jika dibandingkan dengan kelompok lainnya pada abad pertama. ${ }^{31}$ Istilah peripatetic berasal dari peripatetin, kata kerja bahasa Yunani, yang berarti berjalan-jalan. Ini merupakan kebiasaan Aristoteles yang mempunyai gaya mengajar condong berjalan hilir mudik sambil berbicara dengan para murid tentang berbagai ilmu atau masalah tertentu. Dia mengajarkan logika, ilmu alam, ilmu hayat, ilmu bintang, ilmu jiwa dan etika. Pada abad pertengahan di Eropa Barat kurikulumnya kembali dihidupkan dalam bentuk yang dikenal sebagai Ketujuh Pokok Seri Liberal (Septem Ars Liberales). ${ }^{32}$

Golongan Pythagorean telah hadir, khususnya di antara para pengikut Neopythagorean yang telah mulai pada abad pertama sebelum Masehi, yang memperkuat sebuah kesungguhan agama pribadi berdasarkan wahyu dan cenderung pada paham asketik. Kelompok ini telah mempengaruhi beberapa orang dari kelompok Platonisme, dan di Roma sangat berhubungan dekat dengan Stoikisme. Sebagai suatu tubuh, kelompok Pythagorean kelihatannya menghilang pada abad

\footnotetext{
${ }^{30}$ Shedd, A History of Christian Doctrine, 61.

${ }^{31}$ Latourette, A History of the Expansion of Christianity, The First Five Centuries, 17.

${ }^{32}$ Robert R. Boehlke, Sejarah Perkembangan Pikiran dan Praktek Pendidikan Agama Kristen, dari Plato sampai Ig. Loyola (Jakarta: PT BPK Gunung Mulia, 1991), 9.
} 
kedua sesudah Kristus, mungkin muncul kembali melalui kelompok Platonisme yang berubah. ${ }^{33}$

Golongan Stoik, mungkin kelompok ini merupakan agen yang paling utama dalam pembaharuan moral. Mereka dipastikan telah memodifikasi kelompok asli Yunani yang terkenal dengan nama itu. Meskipun kelompok ini bersifat kebiaraan, namun makin menambah penggunaan terminologi dualisme yang diambil dari Platonisme. ${ }^{34}$ Pandangan kelompok ini telah meninggalkan suatu filsafat yang berpegang pada pandangan semua manusia adalah sama, menyatakan bahwa dalam pandangan Allah seorang budak mempunyai nilai yang sama dengan seorang bangsawan, mengajarkan persaudaraan universal, mengangkat tinggi keadilan, kemurahan hati, dan persahabatan, dan mempertahankan semua orang sebagai anak-anak Allah, yang berhak membagikan kehidupan yang baik. ${ }^{35}$ Jadi ajaran Stoik telah menjadi karakter orang Romawi, yang merasa dirinya istimewa, tertarik pada moral kepahlawanan di mana prinsip-prinsip filsafat ini berperan penting. ${ }^{36}$ Bagi kebanggaan para bangsawan Romawi, yang menolak untuk mempertahankan kemerdekaan negaranya, dan dalam hati nurani mereka yang merasa cukup, doktrin dari kelompok Stoik ini diterima dengan istimewa. ${ }^{37}$ Lambat laun Kekristenan menang dalam sebuah masyarakat yang moral dan pandangan hidupnya telah sangat dipengaruhi oleh paham Stoik. Akibatnya, kadang-kadang sulit membedakan perubahan apa yang telah disebabkan oleh

\footnotetext{
${ }^{33}$ Latourette, A History of the Expansion of Christianity, The First Five Centuries, 17.

${ }^{34}$ Ibid.

${ }^{35}$ Ibid., 18.

${ }^{36}$ Neander, General History of the Christian Religion and Church, 21.

${ }^{37}$ Ibid.
} 
Kekristenan ataukah perubahan itu disebabkan oleh paham Stoik. Tentunya, ketika paham Stoik yang merupakan suatu kehidupan kelompok pemikir menjadi musnah, yang tinggal adalah jejak kaki pemenang. ${ }^{38}$ Pandangan kelompok Stoik sebenarnya muncul melawan Platonisme, dengan pertentangan antara dunia transenden dari bentuk-bentuk dan dunia empiris dari pengalaman-pengalaman biasa. Paham Stoik menegaskan kesatuan organik dari alam semesta sebagai suatu keseluruhan yang tunggal. Kecerdasan dipertimbangkan menjadi sebuah bentuk yang berbudi dari substansi materi, bagian dari alam semesta yang berapi-api...Tujuan dari orang bijaksana adalah mendapatkan kebaikan sempurna yang akan menjadikan dia merasa dapat berdiri sendiri. Orang yang bijak bukanlah orang yang terpisah dari urusan dunia, namun orang yang berani dan dapat mengendalikan diri dalam pelaksanaan kewajiban-kewajibannya. Konsep ini membolehkan sebuah penafsiran ulang dan penerapan ulang dari kepercayaan Romawi kuno, dan itu menyatukan tindakan etis dan sosial dengan ibadah kepada mahluk tertinggi. Pandangan ini sangat disukai oleh para cerdik cendekiawan Romawi, karena mereka siap mati dengan pedangnya sendiri jika kehormatannya dipertaruhkan, ini menunjukkan idealisme yang ditimbulkan oleh paham Stoik. ${ }^{39}$

Golongan Neoplatoisme, sesuai dengan namanya, beberapa ide dasar berasal dari paham Plato. Sebagai sebuah kelompok yang resmi, Platonisme tidak menonjol pada awal Kekaisaran Romawi, seperti yang dialami oleh kelompok Stoik. ${ }^{40}$ Meskipun demikian kontribusi dari kelompok ini memperlihatkan suatu kehidupan baru dan penuh semangat. Pada abad terakhir dari paham kekafiran, sebelum sistim

\footnotetext{
${ }^{38}$ Latourette, A History of the Expansion of Christianity, The First Five Centuries, 19.

${ }^{39}$ Smart, The Religious Experience of Mankind, 21.

${ }^{40}$ Ibid., 20.
} 
agama dan filsafat dikelompokkan, Neoplatoisme adalah kelompok yang paling terkenal. Di bawah kelompok ini agama kuno telah berdiri untuk terakhir kali. Di dalam paham ini usaha dibuat untuk menghubungkan pikiran kekafiran dengan agama. Kelompok ini percaya dengan sangat tentang satu Allah yang transenden dan pandangan yang melekat, dengan jalan mistik, untuk mencapai kesatuan dengan Dia. Kelompok ini juga membuat ruang bagi ilah-ilah dari politeisme tradisional, dan untuk banyak kepercayaan popular seperti demonologi. ${ }^{41}$

Sejak abad kedua, filsafat Plato yang hidup di Yunani 400 tahun sebelum kelahiran Yesus, asyik juga dipelajari di barat sehingga pandangan-pandangannya sangat mempengaruhi hidup rohani banyak orang yang menaruh minat terhadap soalsoal agama. Filsafat kafir dari Plato yang indah itupun dipengaruni oleh mistik timur, sehingga ia mengajarkan bahwa jiwa berasal dari dunia ilahi yang terang dan murni, tetapi sekarang terkurung dalam zat benda yang gelap dan jahat. Dengan beraskese dan berekstase (yaitu jiwa membumbung dan meninggalkan tubuh seketika untuk bernafas dan bersukaria dalam suasana ilahi; bandingkanlah Petrus "rohnya diliputi oleh kuasa ilahi”) hendaklah manusia berusaha mengembalikan rohnya kepada asalnya itu. Jadi filsafat Plato ini juga bersifat moralistis dan dualisme pantheistis, tak ubahnya dengan kepercyaan rendah dan sederhana dari rakyat yang kurang terpelajar. ${ }^{42}$ Kemudian pada abad ketiga Platonisme yang sudah ditinjau kembali dan dikenal dengan sebutan Neoplatonisme dibeberkan oleh Ammonius Sakkas dan Plotinus. Neoplatonisme menekankan sifat Allah yang transenden, melebihi batas-batas dunia yang nampak. Untuk sementara ajaran ini menjadi alternatif kekafiran untuk menandingi agama Kristen yang

\footnotetext{
${ }^{41}$ Ibid.

${ }^{42}$ Berkhof dan Enklaar, Sejarah Gereja, 4.
} 
bertumbuh cepat. Ajaran ini juga mempunyai pengaruh yang dalam bagi banyak pemikir Kristen semenjak abad keempat. ${ }^{43}$

Ajaran Neoplatonisme bersumber dari ajaran Socrates yang menjadi perintisnya, kemudian melalui muridnya yang hebat yaitu Plato, yang dengan suatu keaslian pikiran dan kreativitasnya, telah menghasilkan kembali filsafat yang mencitrakan Socrates, telah memimpin orang pada suatu kesadaran tentang sebuah keilahian yang diam dalam kehidupan seseorang, dan suatu akal yang tetap ada dalam dunia, menjawab pikiran dari pengikut Stoik, Zeus; namun itu memimpin mereka untuk mengakui keilahian sebagai yang tertinggi, sebagai suatu keberadaan yang tidak berubah, transenden yang menjadi sesuatu; suatu roh yang tertinggi, ditinggikan di atas dunia, jika bukan seorang Pencipta yang bebas tanpa syarat, paling tidak sebagai arsitek dari alam semesta. ${ }^{44}$

Jadi Neoplatonisme berasal dari ajaran Plato, yang dikembangkan oleh pengikutnya yang bernama Plotinus pada abad ketiga. Ide-idenya diuraikan secara rinci kemudian terkenal dengan Neoplatonisme. Pandangan ini telah menyatukan unsur-unsur bukan hanya dari Plato namun juga dari ajaran Stoik dan filsafat Aristoteles. ${ }^{45}$ Menurut Plotinus, mahluk ilahi adalah sebuah tiga serangkai yang kekal. Yang pertama dari tiga serangkai itu, dan sebagai sumber dari anggota yang lain, dia sebut sebagai Yang Kesatu (The One). Itu juga dalam istilah Platonik disebut Yang Baik. Dari situ keluar Inteligensia (Nous), yang adalah unsur kedua dalam tiga serangkai. Di dalam Nous itu berisi beberapa Bentuk (Forms) yang adalah prototype rohani dari dunia yang diciptakan. Nous adalah prinsip di mana Yang Kesatu dan dan beberapa yang lain berpegang bersama dalam suatu kesatuan yang ideal... Susunan ini menunjukkan jalan di mana Plotinus mengerjakan suatu

\footnotetext{
${ }^{43}$ Lane, Runtut Pijar Sejarah Pemikiran Kristiani, 4.

${ }^{44}$ Smart, The Religious Experience of Mankind, 24.

${ }^{45}$ Ibid., 277.
} 
bentuk koheren ide tentang Absolut Yang Tertinggi (The One), Bentuk-bentuk dunia Platonik (in the Nous), Jiwa Dunia dari pandangan Stoik, dan Demiurge pandangan Platonik (the Soul). ${ }^{46}$

Nampaknya Plotinus telah berusaha untuk menjelaskan mahluk ilahi berupa tiga serangkai di atas, dengan menggunakan campuran pola pikir para filsuf Yunani, yaitu pikiran Plato, Stoik, dan Aristoteles. Pada dasarnya, sama seperti para filsuf lainnya, penjelasan tentang satu Allah Yang Maha Tinggi dan transenden telah diupayakan oleh para filsuf. Inilah yang dapat menjadi titik temu antara pikiran filsafat dengan Kekristenan, yaitu pengakuan tentang adanya Allah Yang Satu. Meskipun demikian ada banyak kesulitan yang muncul ketika mempertemukan ide-ide ini karena Allah menurut konsep filsafat Yunani berbeda dengan Allah menurut Kekristenan. Perbedaannya terletak pada tak berubahnya Allah menurut konsep filsafat Yunani, yaitu Dia tidak dapat berhubungan langsung dengan dunia ini. Oleh sebab itu Dia membutuhkan penengah antara Dia dengan dunia. Nama yang lazim dipakai oleh para pemikir Yunani untuk perantara ini adalah Logos, yang berarti Akal atau Firman. Konsep Allah yang sejati dengan Firman sebagai perantaraNya jelas ada persamaannya dengan Yohanes pasal 1, dan inilah titik pertemuan bagi para apologet Kristen. ${ }^{47}$

Dari uraian di atas nampak adanya gambaran tentang filsafat Yunani yang telah mempengaruhi keadaan keagamaan di wilayah Kekaisaran Romawi pada permulaan Kekristenan. Di kalangan rakyat kebanyakan, pikiran filsafat Epicurean banyak disukai oleh mereka, sedangkan di kalangan para bangsawan banyak memegang filsafat Plato maupun Neoplatonisme. Secara keseluruhan, filsafat telah mempengaruhi kehidupan manusia pada masa Kekristenan awal. Dengan demikian

\footnotetext{
${ }^{46}$ Ibid.

${ }^{47}$ Lane, Runtut Pijar Sejarah Pemikiran Kristiani, 5.
} 
Gereja itu sendiri juga telah dipengaruhi oleh pikiran-pikiran filsafat. Meskipun para filsuf bukanlah orang-orang Kristen, dan para rasul tidak dipengaruhi atau sedikit saja dipengaruhi oleh pikiran-pikiran spekulasi para filsuf, namun pada masa Kekristenan lahir dan berkembang ternyata pikiran filsafat telah sangat mempengaruhi orangorang Kristen. Dalam kenyataannya meskipun filsafat Yunani telah tersebar luas di mana saja, namun itu justru telah membantu persiapan untuk datangnya Yesus Kristus ke dunia. Banyak di antara para penganut filsafat yang asketik maupun skeptik telah berbalik dari kepercayaan-kepercayaan mistik menjadi orang-orang yang sesungguhnya lapar dan haus akan Allah yang benar, dan mereka sangat meninggikan jiwa manusia serta nilainilai moral yang benar. ${ }^{48}$

Selain pikiran filsafat, masih ada hal-hal lain lagi yang terkait dengan situasi keagamaan itu pada masa Kekristenan awal, yaitu berupa kepercayaan-kepercayaan pada roh-roh, mimpi-mimpi, mujizat-mujizat, astrology, ramalan-ramalan, dan sebagainya. Ini merupakan bagian dari agama-agama misteri yang dipercayai oleh sebagian besar orang pada masa itu.

\section{Agama-agama Misteri}

Agama-agama ini telah berkembang di beberapa wilayah, seperti: Anatolia, Persia, dan Mesir. Dalam berbagai cara mereka berbeda, namun tujuan dan garis besar kepercayaan mereka memperlihatkan kesamaan. Pada umumnya tujuan mereka adalah untuk membebaskan anggota-anggota mereka dari belenggu kedagingan dan memastikan sebuah kebahagiaan dalam ketidakbinasaan. Keadaan ini dicapai melalui kesatuan dengan ilah-ilah penyelamat yang telah mati dan bangkit kembali. Kesatuan itu diperoleh melalui suatu upacara dan ritual-ritual seperti makan bersama di mana para

\footnotetext{
${ }^{48}$ Robert A. Baker, A Summary of Christian History (Nashville: Broadman \& Holman Publishers, 1994), 3. (Terjemahan Langsung).
} 
anggota berpartisipasi. ${ }^{49}$

Apa sebab timbul perhatian pada agama-agama misteri ini? Karena pokok utama agama itu adalah kelepasan yang dijanjikan kepada manusia, yakni kelepasan dari segala kesukaran di dunia ini. Kehidupan yang penuh kesusahan di bumi ini dipandang sebagai persediaan saja untuk kehidupan yang sempurna dan baka di akhirat kelak. Tujuan yang indah dan mulia itu harus dikejar dengan beraskese yakni bertarak atau menahan diri, mematikan hawa nafsu daging, dan dengan mengambil bagian dalam berbagai upacara rahasia (misteri), yang melukiskan dan mengusahakan kemenangan hidup atas maut. ${ }^{50}$ Lagi pula agama-agama ini memberi manusia suatu kebajikan yang baru, suatu perasaan keamanan dan perlindungan yang menghiburkan hati, serta pengharapan yang sungguh akan dibebaskan kelak dari segala kesulitan dan kesengsaraan yang diderita oleh tubuh dan jiwa dalam hidup yang fana ini. ${ }^{51}$

Dari abad pertama sampai ketiga berkembanglah ibadah kepada dewa-dewa asing di seluruh Kekaisaran Romawi. Penyembahan kepada dewi Isis yang berasal dari mitologi Mesir kuno, kemudian penyembahan kepada Sarapis yang berasal dari Osorapis yaitu dewa yang tergabung dari sifat-sifat Osiris dan dewa Apis. Jadi pusat penyembahan tertuju pada tiga dewa, yaitu Osiris (atau Sarapis), Isis, dan Horus (anak laki-laki mereka), namun anggota yang dominan dari tiga dewa itu adalah para dewi. ${ }^{52}$ Dari penjelasan di atas, ada istilah yang sering digunakan pada masa kini yaitu sinkretisme yang telah mencampuradukkan agama-agama misteri tersebut di atas karena anggapan bahwa dewa-dewi tersebut di atas adalah sama saja. Mereka

\footnotetext{
${ }^{49}$ Latourette, A History of the Expansion of Christianity, The First Five Centuries, 22.

${ }^{50}$ Berkhof dan Enklaar, Sejarah Gereja, 2

${ }^{51}$ Ibid.

${ }^{52}$ Smart, 279.
} 
dianggap hanya berbagai nama dari suatu zat ilahi yang am saja. ${ }^{53}$ Bahkan jenis agama ini dapat juga disebut dengan pantheisme dan dualisme. Pantheisme ialah kepercayaan bahwa semua (= pan), yakni alam dan segala isinya, termasuk manusia juga, bersifat ilahi. Ilah (= theos) itu ada di dalam segala sesuatu dan tiap-tiap barang atau mahluk mengandung zat ilahi yang esa itu. Dengan demikian ilah itu tidak berpribadi. Menurut dualisme, dunia ini terbagi atas dua bagian yang bertentangan, yakni yang nampak dan yang tidak nampak, zat benda dan roh, tubuh dan jiwa yang lahiriah yang jahat dan yang batiniah yang baik. ${ }^{54}$ Pandangan-pandangan ini sangat bertolak belakang dengan ajaran Kekristenan, namun itu sempat mempengaruhi cara anggota-anggota gereja mengungkapkan iman mereka.

\section{Kondisi Keagamaan Orang Yahudi}

Di tengah-tengah kecanduan pendewaan dalam bentuk Polyteisme dan Pantheisme pada masa awal Kekristenan, dapat diketemukan sekelompok orang yang beriman kepada satu Allah Yang Maha Kuasa, yaitu Dia yang sepenuhnya adalah Sang Pencipta dan Penguasa Dunia, yang disebarkan bukan seperti doktrin iman yang hanya diketahui oleh sebagian orang saja, namun sebagai suatu milik umum bagi semua orang, sebagai pusat dasar yang menghidupkan semua orang dan negara. ${ }^{55}$ Orang-orang Yahudi telah dilatih oleh Allah untuk menjadi alat dalam memelihara dan menyebarkan tentang Allah Yang Hidup, yang kepada siapa semua agama memiliki eksistensi dan perkembangan progresif. ${ }^{56}$ Dapat dikatakan bahwa orang Yahudi telah dipercayai dengan tugas untuk menyampaikan tentang penyataan Allah Yang Hidup

\footnotetext{
${ }^{53}$ Berkhor dan Enklaar, 3.

${ }^{54}$ Ibid.

${ }^{55}$ Neander, 48.

${ }^{56}$ Ibid.
} 
kepada umat manusia. Inilah yang membedakan bangsa Yahudi dengan bangsa yang lain. Penyataan dan pemeliharaan yang Allah berikan kepada mereka ditujukan untuk semua ras umat manusia, yang di atasnya fondasi diletakkan, Kerajaan Allah pada waktunya akan diluaskan. ${ }^{57}$ Jadi melalui bangsa Yahudi maka Kerajaan Allah akan melingkupi seluruh umat manusia. Hal inilah yang menyebabkan pentingnya mengaitkan antara bangsa Yahudi dengan bangsa-bangsa lain di bumi ini.

Dalam hubungannya dengan Kekristenan, maka berikut ini akan diuraikan tentang apa yang menjadi hakekat kehidupan orang Yahudi dan bagaimana itu berpengaruh pada hakekat keagamaan mereka, serta bagaimana dampaknya bagi Kekristenan pada masa tiga abad pertama sejak lahirnya sampai perkembangannya yang begitu cepat.

Mengapa Kekristenan tidak dapat dipisahkan dari Keyahudian? Apapun yang mau dijelaskan tentang Kekristenan, ternyata tidak dapat dilepaskan dari Keyahudian karena Kekristenan bertumbuh dari Keyahudian. Dalam memahami perkembangan Kekristenan, khsusunya pada masa kelahirannya, adalah penting untuk memahami sifat dan perkembangan dari Keyahudian itu.

Beberapa sifat Keyahudian seharusnya digambarkan di dalam bagian yang terkait dengan letak geografis dan keadaan budaya di mana itu bertumbuh. Tempat asalnya secara tradisi adalah berada dekat jalan raya penting antara beberapa pusat budaya yang kuat pada masa dunia kuno. Sepanjang jalan ini bergeraklah perdagangan dan kekuatan militer dari Mesir, Babilonia, Asiria, dan Persia, kemudian dilanjutkan terus sampai masa Alexander dan orang-orang Yunani, bahkan masih berjalan sampai masa Kekaisaran Romawi. Dekat dengan itu adalah orang-orang Punisia dan Philistin. Oleh karena itu orang

${ }^{57}$ Ibid. 
Yahudi tunduk pada pengaruh semua budaya yang telah membantu untuk membentuk dunia Mediteranian kuno. ${ }^{58}$

Jika mengamati sisi agama orang Yahudi, maka ada sumbangsih dari beberapa agama dan budaya yang berbeda, yang telah menyentuh mereka. Di dalamnya diketemukan ada unsur-unsur dari Mesir, Babilonia, Siria, dan Persia. Kemudian ideide dari Yunani juga mempengaruhinya. Latar belakang padang pasir juga dapat dilihat. Mereka terpencar meliputi seluruh dunia kuno, beberapa orang karena pembuangan secara paksa, dan beberapa orang dengan perpindahan secara sukarela, sehingga orang Yahudi menjadi lebih tunduk pada pengaruh-pengaruh asing. ${ }^{59}$ Dari suku-suku orang Yahudi dapat diketahui bahwa mereka berada di bawah nama bersama yaitu Israel yang adalah aslinya sebagai suatu bangsa yang semi nomadik, dan umat yang menjadi penggembala di pedusunan. Hanya ketika mereka mulai menaklukkan Palestina, tidak diketahui pastinya, meskipun ada yang memperkirakan waktunya pada abad keempat belas Sebelum Masehi, tentunya itu dilanjutkan dalam beberapa abad dan tidak mudah menyelesaikannya. Sebelum itu tanah Palestina telah diduduki oleh beberapa kelompok suku yang berbeda. ${ }^{60}$ Dari sisi pemerintahan, orang Yahudi berada di bawah kekaisaran Persia, yang telah diikuti tidak berapa lama sesudah kepunahan dua Negara kecil yang terakhir, maka orang Yahudi memperoleh kembali pemerintahan sendiri. Dalam waktu yang relatif singkat pada abad kedua dan pertama Sebelum Kristus, di bawah pemerintahan Yunani yang meneruskan kekaisaran Persia, orang Yahudi mencapai suatu kepastian jumlah untuk otonomi dan mengatur sebuah Negara kecil dipimpin oleh

\footnotetext{
${ }^{58}$ Latourtee, 31.

${ }^{59}$ Ibid.

${ }^{60}$ Ibid.
} 
para imam. Pada gilirannya mereka tunduk pada pertumbuhan Kekaisaran Romawi. Pemberontakan yang sangat menyedihkan pada permulaan masa Kekristenan membawa pada berakhirnya simbol arsitektur tradisional dari kesatuan agama-agama. $^{61}$

Dari segi politik, tiada seorangpun dari orang Yahudi maupun nenek moyangnya adalah penting. Negara-negara yang mereka atur, secara relatif begitu kecil dan tidak berarti. Namun agama mereka dan yang terkait dengannya, itu mempunyai perjalanan yang panjang dan sangat berarti. Bahkan sebelum Kekristenan bangkit, agama Yahudi telah mempunyai sebuah sejarah yang panjang dan telah memperlihatkan suatu tanda perkembangan. Permulaannya dan banyak bagianbagian dari sejarahnya diselimuti dalam ketidakpastian waktu. Itu nampak jelas bahwa pada permulaan pikiran Israel tentang Yahweh, Allah mereka, adalah sebagai keilahian suku bangsa. Dia telah memilih mereka dan mereka telah menerimanya berdasarkan pada suatu perjanjian yang di dalamnya masing-masing menerima persyaratan-persyaratan tertentu. ${ }^{62}$

Salah satu unsur di dalam keagamaan orang Yahudi yaitu sinagoge. Tidak diketahui kapan sinagoge mulai muncul. Nampaknya itu telah berwujud pada abad keempat dan ketiga Sebelum Masehi. Mungkin sinagoge telah mulai terbentuk pada waktu orang Yahudi berada di tanah-tanah orang asing. Pada masa Kristus, sinagoge diketemukan bukan hanya di antara orang Yahudi di perantauan, namun juga di Palestina dan bahkan di Yerusalem. Sinagoge merupakan tempat untuk beribadah dan mengajar. Ibadah yang dilakukan tanpa mempersembahkan korban di Bait Allah, dan

\footnotetext{
${ }^{61}$ Ibid, 32

${ }^{62}$ Ibid., 33.
} 
upacaranya berisi doa-doa dan pembacaan dari Kitab Suci. Seringkali, jika ada seorang yang berkompeten hadir, pelayanannya termasuk berkotbah. Juga seringkali sebuah sekolah terletak di samping sinagoge untuk pengajaran yang lebih rinci. Sinagoge menjadi karakteristik dari pusat-pusat Keyahudian dan oleh karena itu menjadi bagian yang berperan sangat penting dalam menghidupkan iman. Sinagoge-sinagoge itu mempunyai sebuah peran yang penting dalam penyebaran Kekristenan awal dan mungkin telah membantu menetapkan organisasi dan upacara orang Kristen. ${ }^{63}$

Unsur lain yang perlu dipahami yaitu adanya kanon tulisan-tulisan yang dianggap mempunyai otoritas, yang kemudian diambil alih oleh orang Kristen sebagai Perjanjian Lama. Tulisan-tulisan ini dilengkapi dengan tradisi lisan, banyaknya penafsiran dan eksegesa. ${ }^{64}$ Selain itu juga muncul Midrash yang merupakan eksposisi dari pendidikan karakter moral. Itu semua telah mempengaruhi literatur Kristen pada abad pertama, bahkan beberapa bagian Injil-Injil memasukkan gaya itu. Salah satu gaya literature yang telah mempengaruhi Kekristenan adalah apocalypse atau pewahyuan. Tulisan ini dipercayai menjadi inspirasi yang bersifat ilahi dan datang dengan sebuah penglihatan atau sebuah mimpi yang biasanya ditafsirkan oleh seorang malaikat dan bertujuan untuk memberitahukan tentang apa yang akan terjadi pada masa mendatang. ${ }^{65}$ Hal yang paling dekat dengan pewahyuan yaitu konsep tentang seorang Mesias. Konsep ini sangat menonjol di dalam

Kekristenan, dan di bawah bentuk bahasa Yunani, Kristus telah memenuhi nama itu. Di lingkungan Keyahudian terdapat Hellenistik Yudaisme yang menonjol di dalam kehidupan orang-orang Yahudi di luar tanah asal mereka, di mana mereka telah

\footnotetext{
${ }^{63}$ Ibid.

${ }^{64}$ Ibid.

${ }^{65}$ Ibid., 37.
} 
mewarisi iman yang dimodifikasi dengan kebudayaan Yunani. Pengaruh kebudayaan ini terasa di Palestina bahkan di Yerusalem. Di luar Palestina mungkin macam kebudayaan ini berbeda dengan yang ada di Yudea di mana kebudayaan Yunani telah mempunyai pengaruh yang kecil. Meskipun demikian, baik di Palestina maupun Hellenistik Yudaisme adalah suatu kesatuan. Masing-masing berperan dalam bentuk yang bermacam-macam. Salah seorang pemikir Hellenistik Yudaisme yang paling terkenal adalah Philo dari Alexandria. Dia menggabungkan antara Yudaisme dengan pikiran Yunani. Dia sendiri adalah seorang penganut mistik, yang bagi dia obyek dari perjuangan jiwa adalah sebuah penglihatan segera dari Allah. Bagi dia Platonisme, Stoikisme, dan Pythagoreanisme serta Yudaisme telah meninggalkan tanda mereka. Dari filsafat Yunani, yaitu Platoisme dan Stoikisme telah membuat kesan yang mendalam. Di antara tujuan-tujuan lain dalam tulisan-tulisannya, dia telah berusaha untuk menjembatani jurang pemisah antara Allah dengan dunia yang dijadikanNya, melalui Logos. ${ }^{66}$ Dalam berbagai cara Hellenistik Yudaisme telah membuktikan suatu keuntungan yang berbeda bagi Kekristenan, misalnya dengan penggunaan terjemahan Kitab Suci. Begitu pula dengan Paulus, seorang Yahudi Hellenistik, telah menjadi tokoh utama dalam membawa iman Kristen kepada orang-orang bukan Yahudi. Ke dalam sinagoge di perantauan, para misionari Kristen seringkali masuk untuk menyajikan berita mereka. Dari antara anggota-anggota Yahudi dan peserta dari bukan Yahudi yang ada di dalam sinagoge itu, telah datang orang-orang Kristen baru. Lebih lagi bagi Hellenistik Yudaisme, Kekristenan bukan Yahudi nampak mempunyai beberapa konsepnya sendiri. ${ }^{67}$

Berikut ini akan dijelaskan tentang para teolog di lingkungan orang Yahudi,

\footnotetext{
${ }^{66}$ Ibid., 42.

${ }^{67}$ Ibid., 43.
} 
yang dapat diketemukan dalam tiga arah utama, yaitu:

Pertama, kecenderungan tradisional, yang bercampur dengan agama asli beberapa unsur agama asing, mencampurkannya ke dalam tiruan yang menyatu, dan di mana di dalamnya kehilangan kehidupan rohani, memegang kuat bentuk dan huruf, menggantikan tempat hakekat nyata dari agama, suatu orthodoxy yang keras dan serangkaian upacara yang mati. ${ }^{68}$

Kedua, timbul sebuah reaksi yang cenderung untuk merubah. Namun sebuah reaksi macam ini, cara bekerjanya lebih intelektual dari pada sebuah unsur keagamaan, yang mengijinkan semangat penyangkalan yang menguasai pada daya tarik keagamaan yang positif, dengan mudah membelokkan sikap yang berlebihan dalam polemik, dan dalam waktu yang ekstrim seringkali menghilangkan unsur-unsur asing, yang kebanyakan asli dan baik. ${ }^{69}$

Ketiga, ketidakpuasan terhadap kedua kecenderungan di atas tinggal dalam orang-orang yang besar dan berperasaan hangat, biasanya memberi reaksi pada reaksi yang lain, yaitu reaksi yang mendahului tendensi subyektif, yang akan memberi otoritas tertinggi pada perasaan-perasaan dan penghakiman-penghakiman secara intuisi, dan sebagai perlawanan pada tendensi-tendensi yang telah dijelaskan di atas, dirancangkan dengan nama mistisisme..$^{70}$

Tiga kecenderungan di atas dapat dikategorikan ke dalam tiga istilah yang banyak dikenal sekarang dengan Orang-orang Parisi, Orang-orang Saduki, dan orang-

${ }^{68}$ Neander, 53.

${ }^{69}$ Ibid.

${ }^{70}$ Ibid. 
orang Essene.Orang-orang Parisi, menjabat kepala Yudaisme yang sah. Mereka memagari keliling hukum Musa dengan sebuah kelompok orang yang disebut "para pembendung“(hedges), di mana aturan-aturannya menjadi penjaga melawan setiap kemungkinan pelanggaran. ${ }^{71}$

Orang-orang Saduki, dipihak lain, merindukan untuk mengubah agama yang berdasarkan hukum Musa kepada kemurnian aslinya, dan menghapus apapun yang telah ditambahkan oleh tradisi paham Parisi. ${ }^{72}$

Orang-orang Essene, muncul sekitar dua abad sebelum kelahiran Kristus, di sebuah desa yang sepi terletak di sebelah barat Laut Mati, sebuah masyarakat yang orang-orangnya cenderung saleh, yang mencari di dalam kesunyian ini sebuah tempat perlindungan dari korupsi yang merajalela, dari kelompok-kelompok yang berselisih, dan keributan serta percekcokan dunia. Masyarakat mereka bertumbuh justru sebagai sistem kebiaraan pada periode kemudian. ${ }^{73}$

Apa hubungan kelompok-kelompok orang Yahudi seperti diuraikan di atas dengan Kekristenan? Dalam kaitan dengan kelompok orang Saduki, yang mengawasi setiap aspirasi yang melebihi batas-batas keberadaan keduniawian, itu menyajikan suatu titik kontak dengan Injil. Paling tidak, ketika melalui perasaan manusia yang sederhana, yang tidak dapat ditekan secara keseluruhan, itu kadang-kadang menemukan jalan masuk di antara orang-orang Saduki, seperti yang telah terjadi di manapun, sebelumnya cara mereka berpikir sama sekali tidak mempersiapkan jalan pada suatu perpalingan. ${ }^{74}$ Sedangkan dalam kasus orang-orang Parisi, kesombongan

\footnotetext{
${ }^{71}$ Ibid., 54.

${ }^{72}$ Ibid., 55.

${ }^{73}$ Ibid., 59.

${ }^{74}$ Ibid., 87.
} 
rohani, pembenaran diri sendiri, kedangkalan dan kesombongan dalam pengetahuan tentang Kitab Suci, dan kekosongan kualitas yang dimiliki oleh orang-orang yang disebut Tuhan sebagi miskin rohani, itu semua pada umumnya adalah hambatan-hambatan bagi iman. Kita harus berhati-hati untuk membedakan di antara orang Parisi dua kelompok yang telah ditunjukkan. ${ }^{75}$ Bagi siapa yang berada pada posisi legal, berjuang dengan sebuah kejujuran yang sungguh pada kebenaran, hukum, tanpa ragu, pada akhirnya melayani sebagai sarjanasarjana sekolah untuk membawa mereka kepada Kristus. Contoh: Rasul Paulus yang telah menceritakan pengalamannya pada tujuh pasal dalam Kitab Roma, orang-orang seperti itu dapat memperoleh damai sejahtera melalui kepercayaannya. ${ }^{76}$ Sedangkan di sisi lain, barangsiapa datang pada Kekristenan tanpa melewati suatu krisis dari dalam kehidupan mereka, besar kemungkinan pada percobaan mencampurkan cara berpikir mereka sebagai orang Parisi dengan pengenalan Yesus sebagai Mesias, yang bagi mereka bukanlah Juruselamat yang benar, dan berharap pada saat yang sama berpegang pada usaha pembenaran mereka. ${ }^{77}$

Di dalam Kekristenan sebuah unsur mistik telah hadir. Ini terkait dengan penjelasan tentang pikiran keagamaan yang berkembang di dalam masyarakat Essene dan Therapeutae. Namun unsur mistik jika dibawa pada ekstrim yang tak semestinya, dapat menyesatkan manusia pada lingkaran perasaan dan intuisi, dan menghalangi hati mereka melawan setiap pengaruh lain yang dapat berjuang untuk menembus mereka. ${ }^{78}$ Berdasarkan uraian di atas dapat dikatakan bahwa Gereja Kristus mulai timbul di tengah bangsa Yahudi, dan pekabarannya pertama-tama ditujukan kepada orang

\footnotetext{
${ }^{75}$ Ibid., 88.

${ }^{76}$ Ibid.

${ }^{77}$ Ibid.

${ }^{78} \mathrm{Ibid}$.
} 
Yahudi dalam perserakan. ${ }^{79}$ Meskipun kehidupan orang Yahudi pada masa itu berada di bawah penjajahan pemerintahan kekaisaran Romawi, namun kehidupan keagamaan orang Yahudi adalah bebas, artinya mereka berhak menyembah Allah menurut hukum-hukum tauratnya. Agamanya dipimpin oleh Majelis "Sanhedrin” yang anggotanya terdiri dari imamimam dan ahli-ahli taurat, 70 orang banyaknya, dan diketuai oleh seorang iman besar. Pusat agama Yahudi adalah Bait Allah di Yerusalem, tetapi kebanyakan orang Yahudi tak sempat berbakti ke sana, sehingga tiap-tiap jemaat Yahudi dibangunkan rumah ibadah (sinagoge), tempat mereka berhimpun pada hari Sabbat di bawah pimpinan ahli-ahli Taurat. Lambat laun golongan ahli Taurat itu lebih berkuasa dari para imam. ${ }^{80}$ Jadi dapat disimpulkan bahwa Kekristenan telah lahir ke dalam dunia Mediteranian, yang merupakan pusat dari bermacam-macam peradaban dunia pada masa itu. Di samping itu terdapat Yudaisme yang telah berkembang dan dipakai sebagai suatu dorongan bagi munculnya suatu kepercayaan yang baru dan asli, lebih dari pengalaman keagamaan umat manusia sebelumnya, dan di dalamnya Kekristenan telah menjadi ahli warisnya. Kekristenan juga telah lahir hampir sejaman dengan Kekaisaran Romawi, dan telah mengambil keuntungan dari kedamaian, kesatuan politik, kebudayaan, perdagangan, dan kesatuan bahasa yang ada.

Konteks di mana gereja lahir dan berkembang telah memberikan gambaran bagi Gereja masa kini bahwa Kekristenan telah lahir dalam dunia yang tidak nihil. Usaha-usaha perluasan Kekristenan dari waktu ke waktu, selalu diperhadapkan dengan konteks jamannya. Banyak faktor yang telah mempengaruhi lahir dan berkembangnya Kekristenan, baik faktorfaktor yang mendukung maupun faktor-faktor yang menghambat. Itulah kenyataan yang terus

\footnotetext{
${ }^{79}$ Berkhof dan Enklaar, 4.

${ }^{80}$ Ibid, 5
} 
menerus dihadapi oleh Kekristenan dari generasi ke generasi, dari abad ke abad sampai masa sekarang ini. 